\title{
Concurso para livre-docente de Direito Judiciário Civil.
}

Realizaram-se, nos dias 19, 20 e 24 de novembro de 1962, as provas do concurso para livre-docente de direito judiciário civil em que se inscreveu o bacharel Moacyr Lobo da Costa.

A dissertação apresentada pelo candidato intitula-se A intervenção "iussu iudicis" no processo civil brasileiro.

Participaram da comissão examinadora os professôres Noé de Azevedo, Luís Eulálio de Bueno Vidigal, Alfredo Buzaid, Moacyr Amaral Santos e Washington de Barros Monteiro.

A prova escrita realizou-se no dia 19 , tendo sido sorteado o ponto Concurso universal de credores.

A argüição sôbre a tese do candidato realizou-se no dia 20. No dia 24 o candidato fêz a preleção sôbre o tema Substituição processual, e, em seguida, efetuou a leitura da prova escrita, passando a comissão examinadora a proceder ao julgamento das provas, aprovando o candidato com a média geral 9,47 .

A prova escrita do candidato é publicada a seguir com o título, Concurso Universal de Credores.

Concurso universal de credores.

Sumário: 1. Proêmio. 2. Perfil histórico. 3. Antecedentes no direito brasileiro. 4. A interpretação doutrinária do art. 929 do Cód. Proc. Civil. 5. Direito comparado.

6. Dogmática. \%. Condições formais. 8. Conclusão.

1. O tema desta dissertação reveste-se de invulgar interêsse, no campo do direito processual civil, pelas impli- 
cações doutrinárias e práticas, especialmente, pelas investigações que suscita quanto à sua origem histórica e pelas elaborações dogmáticas a que dá margem quanto à sua finalidade.

Comecemos, como é de rigor, então, pelo seu

\section{Perfil Histórico.}

No direito romano uma lei Julia autorizava o devedor insolvente, que quizesse se furtar à execução pessoal da "manus injaectio" e à infamia decorrente, a fazer cessão de seus bens aos credores; era a "bonorum cessio" que, através das vissitudes por que passou o direito romano, na sua trajetória durante a idade média, sob a influência do direito germânico e do dỉreito canônico, veiu a ser acolhida pelo direito português, tendo assento nas ordenações do Reino.

Assim, a ordenação del rei Dom Filipe, no seu livro $4^{\circ}{ }^{\circ}$ título 74, dispôs a respeito "dos que fazem cessão de bens", traçando normas sôbre a admissibilidade dêsse meio jurídico assegurado ao devedor insolvente para se livrar da prisão, bem como das condições para seu exercício e das formalidades exigidas.

A cessão de bens era considerada como um benefício concedido ao devedor e consagrado pela legislação, a fim de que o devedor de boa fé, demonstrando voluntária ou judicialmente a seus credores que a razão do não cumprimento de suas obrigações era o infortúnio e não o dolo, obtinha dêles, por sentença judicial, permissão para começar de novo sua vida, entregando todos os seus bens em pagamento de suas dívidas, mas, sem se exonerar delas, ficando sujeito, logo que adquirisse novos recursos, a solver o saldo devedor verificado, para o que lhe era concedida moratória por cinco anos.

Era indispensável que o devedor demonstrasse, por meio de um inventário, quais os bens que possuía antes de contrair as dívidas e as adversidades que lhe advieram e motivaram o estado de insolvência em que se encontrava. 
Reconhecida a boa fé do devedor o benefício era-lhe concedido.

Mesmo após a supressão da prisão por dívidas, pela lei de 20 de junho de 1774, o benefício da cessão de bens permaneceu em favor do devedor de boa fé. Continuava a ser admitida como uma garantia para o devedor honesto, e segurança de sua tranqüilidade.

\section{Antecedentes no Direito Brasileiro.}

No Brasil, em virtude de não haver sido revogada a ordenação que a concedia, a cessão de bens continuou a ser admitida nas condições em que a regulavam a citada ordenação e as leis posteriores.

Ao se tratar da elaboração de um código civil para o país, dos vários projetos apresentados o do jurisconsulto Coelho Rodrigues acolheu a cessão de bens com a mesma finalidade que lhe era atribuida na vetusta legislação das ordenações, caracterizando-a, contudo, como a figura da insolvência civil.

Clóvis Beviláqua adotou-a no seu projeto; todavia, a despeito da defesa do instituto da insolvência civil, que sustentou contra a opinião do Cons. Andrade Figueira, foi a opinião dêste que prevaleceu na redação do projeto definitivo e se converteu em lei. Assim, o Código Civil Brasileiro não contempla o instituto da insolvência civil, a que equivale o concurso universal de credores provocado pelo próprio devedor, mediante a oferta da cessão de bens, como vinha do direito ancestral, mas, tão sòmente, a figura do concurso de credores, que a doutrina qualifica como concurso particular, a que se procede, como reza o artigo 1554, tôda a vez que as dívidas excedam à importância dos bens do devedor.

O ministro Artur Ribeiro, quando elaborou um projeto de código de processo civil, por incumbência do Govêrno da União, em razão do disposto no art. 11 das disposições provisórias da Constituição de 1934, incluíu o concurso universal de credores como sendo a insolvência civil do 
devedor e estabeleceu as regras de processamento e condições de admissibilidade. O projeto, entretanto, como tantos outros, foi tragado na voragem do regime fascista que se inaugurava no país com o golpe de 10 de novembro de 1937.

A consciência jurídica do eminente mestre desta casa, o prof. Waldemar Ferreira, sempre voltada para o aprimoramento das nossas leis e instituições, fêz-se éco das necessidades e reclamos da vida jurídica do país, e, em primorosa proposição apresentada ao Congresso Nacional de Direito Judiciário Civil, que se reuniu na Capital da República, advogou o estabelecimento da insolvência civil, para o devedor não comerciante, ao lado da falência para o devedor comerciante.

Não seria possivel dizer-se que a memorável proposição tenha caido em terreno sáfaro. Ao contrário, o legislador do código de processo civil, aprovado pelo Decreto-lei n. ${ }^{\circ} 1.608$, de 18 de setembro de 1939 , com o estabelecer a norma constante do art. 929 do estatuto processual, atendeu, embora não de maneira cabal, como seria conveniente, à sugestão do eminente jurista.

Conquanto não tenha instituído o regime da insolvência civil, com suas características e peculiaridades, o certo e indisputável é ter aquêle dispositivo estabelecido o concurso universal de credores, por provocação do devedor, ao lado do concurso particular, de que tratam os artigos 1017 e seguintes, e que se instaura por provocação de qualquer credor, como o demonstrou, de maneira cabal, outro eminente mestre desta Faculdade, o prof. Alfredo Buzaid, na tese de concurso com que conquistou brilhantemente a cátedra de direito processual civil na Faculdade de Direito da Universidade Católica de S. Paulo.

$\mathrm{O}$ artigo 929 do $\mathrm{CPC}$, ao dispor ser lícito ao devedor apresentar relatório de seu estado patrimonial, com a discriminação do ativo e passivo, a fim de que se instaure, desde logo o concurso de credores, com a notificação dos interessados, quando a penhora que recaíu sôbre seus bens não bastar ao integral pagamento do credor exeqüente, 
instituíu, no Brasil, o concurso universal de credores, por provocação do devedor.

\section{A Interpretação Doutrinária do art. 929 do CPC.}

Êsse dispositivo legal, entretanto, até o aparecimento do livro do prof. BuzAID, vinha sendo interpretado diferentemente pelos comentadores do código. Assim é que, considerando-o como, apenas, um incidente do processo da execução, Oswaldo Pinto no Amaral entendeu que o concurso só poderia versar sôbre os bens penhorados e o prof. Amilcar de CASTro sustentou que assim devia ser, na suposição de que penhorados estivessem todos os bens de propriedade do devedor. O prof. Lopes da Costa disse, no seu livro de Direito Processual Civil que êsse artigo 929 tinha um pouco de tudo, pois, equivalia à cessão de bens, dava azo à instauração do concurso de credores, e aquêle relatório de seu estado patrimonial lembrava o $\S 807$, do ordenamento processual civil alemão (ZPo).

Desta última assertiva discordou frontalmente PoNTES DE Mrranda, demonstrando que aquêle dispositivo da lei alemã tinha finalidade diversa.

Só após o trabalho do prof. Buzaid é que a doutrina nacional atentou para o verdadeiro significado e alcance do art. 929 do CPC, como salientou o prof. Pedro Palmeira, em sua tese de concurso, no Rio de Janeiro.

\section{Direito Comparado.}

No direito comparado o instituto do concurso universal de credores, por provocação do devedor, ao lado do concurso particular, por provocação de qualquer credor e da falência para o devedor comerciante, está regulado e foi acolhido pelo CPC português, elaborado sob a orientação do prof. José Alberto dos Reis — artigos 1358 e seguintes, que tratam da insolvência dos não comerciantes; bem como pela "ley de enjuiciamiento civil" espanhola, que trata do concurso de credores, nos artigos 1.156 e seguintes, admitindo 
o concurso universal, por provocação do próprio devedor, nos artigos 1.156 e 1.157 .

\section{Dogmática.}

O concurso universal, tal como está previsto no art. 929 do CPC a despeito de sua ubicação, não é um simples incidente do processo de execução, como se poderia supor, e foi mesmo entendido por alguns. É um processo autônomo.

Esse instituto tem a natureza de provocação da intervenção de terceiros no processo, com a finalidade de obter o reconhecimento do estado de insolvência do devedor e possibilitar o rateio entre todos os credores do produto que fôr apurado com a venda de todos os bens do devedor, de maneira a impedir que o exeqüente se pague integralmente ou preferentemente, com prejuízo dos créditos dos demais credores.

Visa, assim, a realizar a satisfação dos débitos "par conditio creditorum", num juízo universal de liquidação coletiva.

O devedor não propõe uma ação, na verdade, mas, mediante a sua provocação, instaura-se um processo autônomo, com a intervenção dos terceiros credores no processo da execução, assistindo ao devedor a "exceptio concursus pendentis".

Os credores intervenientes assumem a qualidade de litisconsortes, em face do devedor comum, não obstante, inexista laço de comunhão de interêsses que os envolva, de sorte que, entre êles, os interêsses são quasi sempre antagônicos, traduzindo-se o antagonismo na disputa que se pode estabelecer com o objetivo da exclusão de algum dos créditos apresentados.

A sentença que julga o concurso tem a natureza de sentença predominantemente constitutiva, com efeito declaratório. 
Contra a decisão que admitir, ou não, o concurso, ou ordenar a inclusão ou exclusão de créditos, o CPC concede o agravo de instrumento, do art. $842 \mathrm{n} .^{\circ}$ xIII.

\section{Condições formais.}

São condições formais de admissibilidade do concurso universal, por provocação do devedor, no caso do art. 929, que $o$ pedido venha subscrito por procurador judicial com poderes especiais para êsse fim, em razão do disposto no art. 108, do CPC, e, que o relatório, a que se refere o art. 929, individui, com precisão, os credores que deverão ser notificados, bem como o estado patrimonial do devedor com a indicação de seu ativo, constante de todos os bens disponíveis de sua propriedade, e do passivo com a indicação de tôdas as suas dívidas e a sua natureza.

Não há, na lei processual vigente, a exigência de referir o devedor os motivos adversos que o reduziram à insolvência, como constava da legislação ancestral portuguêsa.

\section{Conclusão.}

Em conclusão, podemos afirmar, na companhia de eminente mestre desta Faculdade, que o legislador do estatuto processual civil brasileiro acolhendo, embora, de maneira incompleta e inábil, a sugestão feita por outro dos grandes mestres, de que esta Faculdade se orgulha, instituíu a figura do concurso universal de credores, ao lado do concurso particular, e ao lado da falência do devedor comerciante, tal como se verifica no moderno direito processual civil português e no direito espanhol.

$\mathrm{O}$ relatório, que não se assemelha quanto à sua finalidade, ao de que trata o $\$ 807$ da zpo alemã, não se destina, também, a promover a cessão de bens, eis que os credores serão pagos, afinal, com o produto da venda dos bens.

Por não corresponder, quanto ao seu aspecto formal, ao instituto da insolvência civil, réplica da falência comercial, o concurso universal, previsto no art. 929 do CPC é 
destituído de administração orgânica, o que, na prática, costuma trazer sérios óbices.

Se não fôsse incurial encerrar uma dissertação com um apêlo ao legislador e me fôsse permitido fazê-lo, deixaria consignado aqui meus votos para que, na almejada e esperada reforma do código de processo civil se estabeleça o instituto da insolvência civil, com suas características e peculiaridades, a exemplo do vigente $c p c$ português, como um passo a mais na senda do progresso das nossas leis e instituições jurídicas. 